no.

GL-92-20

c. 2

\title{
USER'S GUIDE: ASPHALT RUBBER AND GEOTEXTILE INTERLAYERS
}

\author{
US-CE-C \\ UNITED STATES GOVERTY OF THE \\ TATES GOVERNMENT
}

by

Randy C. Ahlrich

US Army Engineer Waterways Experiment Station Vicksburg, MS 39180-6199

Approved For Public Release; Distribution Is Unlimited

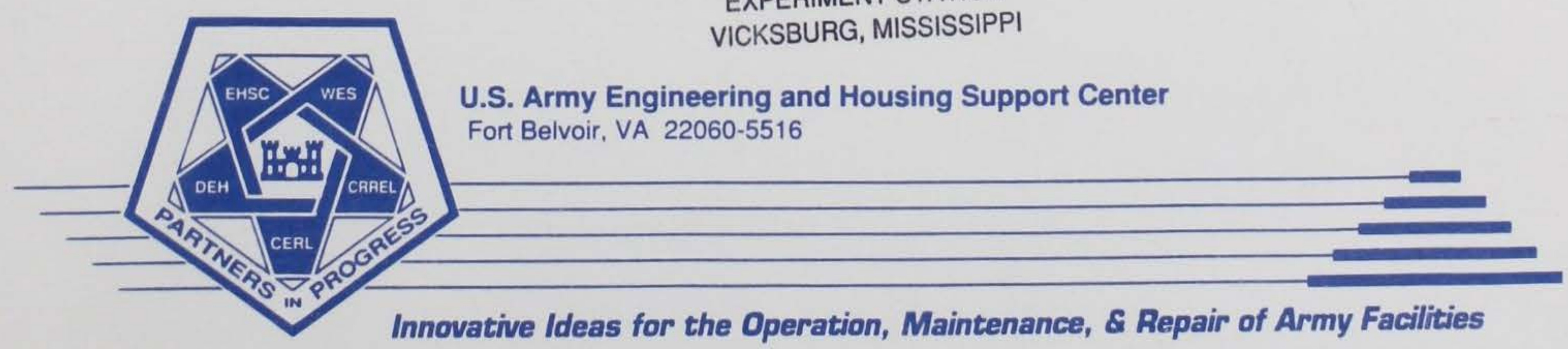




\section{REPORT DOCUMENTATION PAGE}

Pudic reporting burden for this coliection of information is estimated to average 1 hour per response, inciuding the time for reviewing instructions. searching existing data sources gathering and maintaining the data needed. and completing and reviewing the coliection of information. Send comments regarding this burden estimate or any other aspect of this Davis Highway, Suite 1204. Arlington, VA 22202-4302, and to the Ottice of Management and Budget. Paperwork Reduction Project (0704.0188), Washington, DC 20503.

\begin{tabular}{|l|l|l|}
\hline 1. AGENCY USE ONLY (Leave blank) & $\begin{array}{l}\text { 2. REPORT DATE } \\
\text { August } 1992\end{array}$ & $\begin{array}{l}\text { 3. REPORT TYPE AND DATES COVERED } \\
\text { Final report }\end{array}$ \\
\hline
\end{tabular}

\section{TITLE AND SUBTITLE}

User's Guide: Asphalt Rubber and

Geotextile Interlayers

6. AUTHOR(S)

Randy C. Ahlrich

\section{PERFORMING ORGANIZATION NAME(S) AND ADDRESS(ES)}

USAE Waterways Experiment Station

Geotechnical Laboratory

3909 Halls Ferry Road

Vicksburg, MS 39180-6199
5. FUNDING NUMBERS

\section{SPONSORING/MONITORING AGENCY NAME(S) AND ADDRESS(ES)}

US Army Corps of Engineers

Engineering and Housing Support Center

Bldg. 2593

Fort Belvoir, VA 22060-5516

11. SUPPLEMENTARY NOTES

12a. DISTRIBUTION/AVAILABILITY STATEMENT

8. PERFORMING ORGANIZATION REPORT NUMBER

Miscellaneous Paper

GL-92-20

10. SPONSORING/MONITORING AGENCY REPORT NUMBER

FEAP-UG-92/08

Approved for public release; distribution is unlimited.

\section{ABSTRACT (Maximum 200 words)}

One of the shortcomings of asphalt concrete (AC) overlays is the eventual occurrence of reflective cracking. Reflective cracks are fractures in the overlay that occur because of excessive movement of cracks and joints in the underlying pavement layers. Without some form of prevention or reduction of these reflective cracks, early deterioration of an asphalt overlay can occur. The asphalt rubber and geotextile interlayers are used to prevent and reduce reflective cracks and to act as a waterproofing medium when overlaying structurally sound AC and portland cement concrete (PCC) pavements with AC in warm, dry climates. The description, applicability, benefits, limitations, costs, recommended uses, and location of demonstration sites for asphalt rubber and geotextile interlayer technology are discussed.

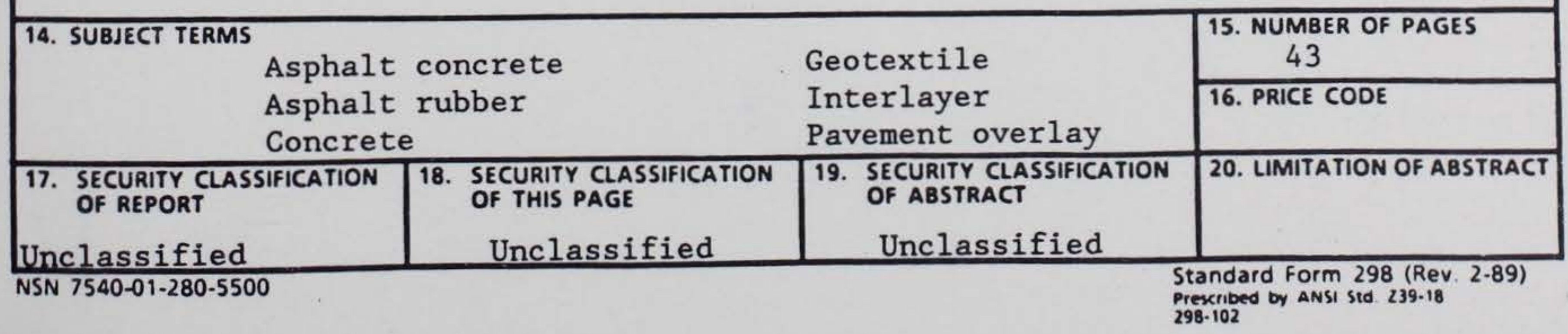


CONTENTS

Page

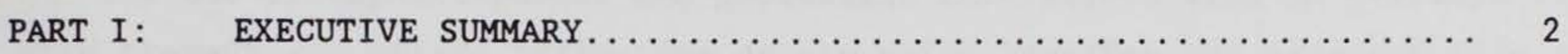

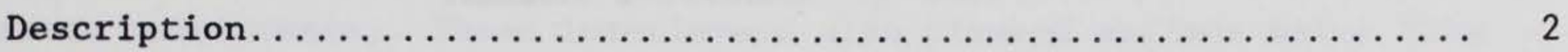

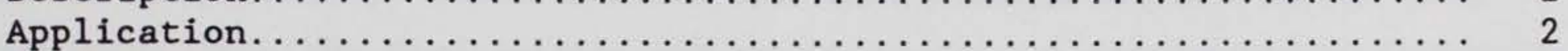

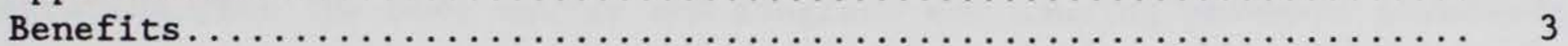

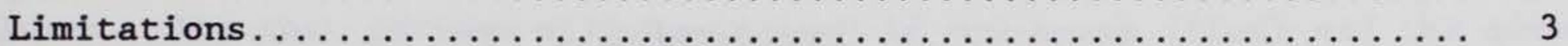

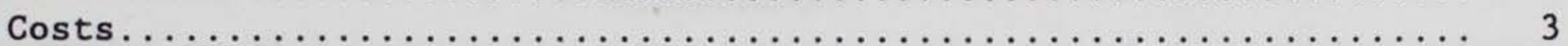

Recommendation for Use........................... 3

Points of Contact................................ 4

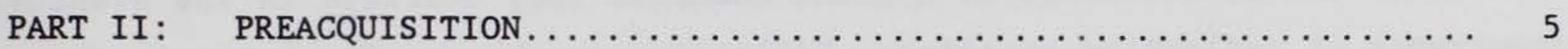

Description of Asphalt-Rubber and Geotextile Interlayers....... 5

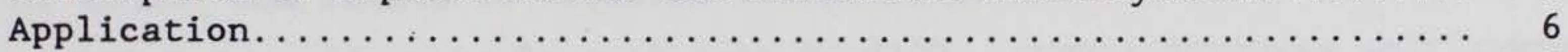

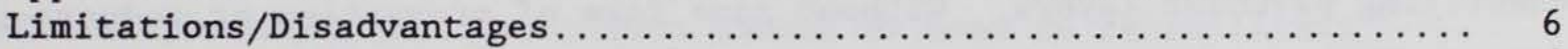

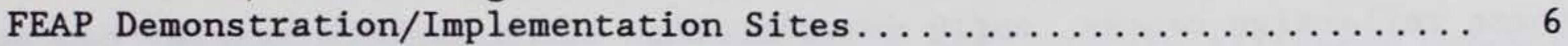

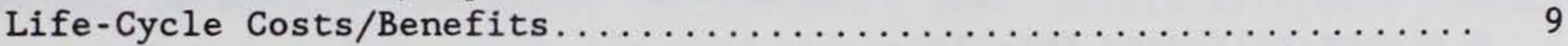

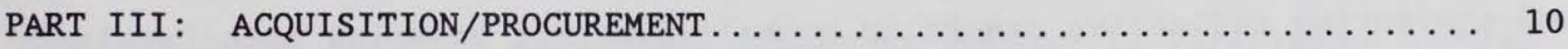

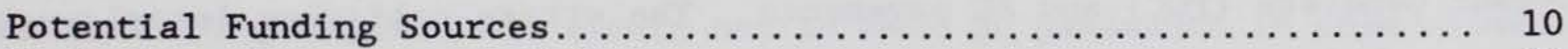

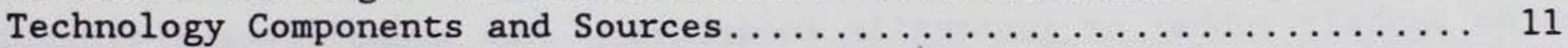

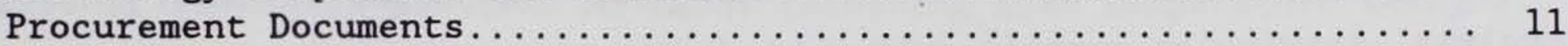

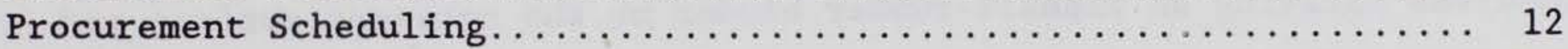

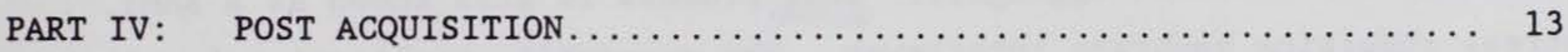

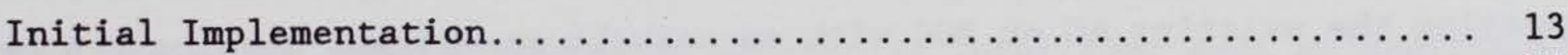

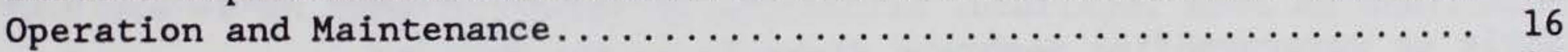

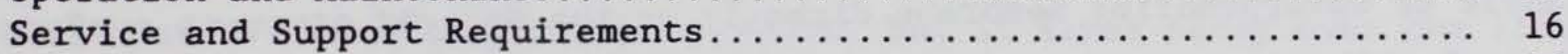

Performance Monitoring. ........................... 16

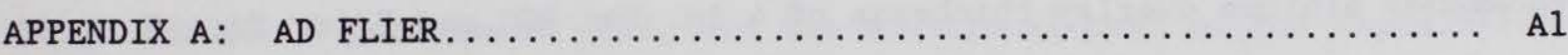

APPENDIX B: ENGINEER TECHNICAL LETTER $\ldots \ldots \ldots \ldots \ldots \ldots \ldots \ldots \ldots \ldots \ldots \ldots \ldots$

APPENDIX $c:$ GEOTEXTILE INTERLAYER FACT SHEET $\ldots \ldots \ldots \ldots \ldots \ldots \ldots \ldots \ldots \ldots$

APPENDIX D: CONTRACT AND MANUFACTURER SPECIFICATIONS $\ldots \ldots \ldots \ldots \ldots \ldots$ DI 


\section{PART I: EXECUTIVE SUMMARY}

\section{Description}

One of the shortcomings of asphalt concrete (AC) overlays is the eventual occurrence of reflective cracking. Reflective cracks are fractures in the overlay that occur because of excessive movement of cracks and joints in the underlying pavement layers. Without some form of prevention or reduction of these reflective cracks, early deterioration of an asphalt overlay can occur.

A stress-relieving interlayer has been one successful method in retarding and preventing reflective cracks in asphalt overlays covering both Portland Cement Concrete (PCC) and AC pavements. The stress-relieving interlayer can be an asphalt rubber or geotextile interlayer. The asphalt-rubber interlayer involves spraying an asphalt-rubber binder on the pavement surface and covering with a coarse aggregate. This process is also known as a SAMI, stress absorbing membrane interlayer. The geotextile application involves spraying the existing AC or PCC with an asphalt cement and placing synthetic fabric or waterproofing membrane directly on the sprayed pavement surface. The rehabilitation technique is completed by placing an AC overlay. USACE recommends minimum overlay thickness of 4 in. for PCC and 2 in. for AC.

\section{Application}

The asphalt-rubber and geotextile interlayers are used to prevent and reduce reflective cracks and to act as a waterproofing medium when overlaying structurally sound AC and PCC pavements with AC in warm, dry climates. (Appendix A). 


\section{Benefits}

The use of asphalt-rubber and geotextile interlayers with AC overlays will help prevent and retard reflective cracks which lengthen the pavement life and decrease maintenance. These interlayers also prevent surface water from penetrating into the base course and subgrade and causing pavement structural failures. The cost savings will be noticed in man-hours (time) and the amount of material needed to maintain the pavement. The use of these interlayers can provide a pavement with many years of maintenance-free service.

\section{Limitations}

These rehabilitation techniques cannot be used to rehabilitate structurally unsound pavements. AC pavements that contain alligator cracking or weak base courses and PCC pavements with shattered or failed slabs must be repaired prior to using an asphalt-rubber or geotextile interlayer. These stress-relieving interlayers should not be used on pavements in cold climates because of increased pavement movement resulting from temperature changes.

\section{$\underline{\text { Costs }}$}

The use of an asphalt-rubber or geotextile interlayer adds an additional initial cost to the rehabilitation project, but it saves money over the life of the pavement. The unit cost of a typical geotextile interlayer is between $\$ 0.25$ and $\$ 1.00$ per square yard, and the additional cost of the asphalt-rubber interlayer is between $\$ 1.00$ and $\$ 2.50$ per square yard.

\section{Recommendation for Use}

The asphalt-rubber and geotextile interlayers rehabilitation techniques are recommended for structurally sound AC and PCC pavements. The existing pavement should be relatively smooth and should have negligible movement under traffic. These interlayers when properly applied are successful in preventing or retarding reflective cracks in mild, dry climates. Specific guidance on 
the use of these interlayers within the U.S. Army Corps of Engineers is given in Appendix B.

\title{
Points of Contact
}

\author{
Points of contact regarding this technology are: \\ Technical: \\ Director \\ US Army Engineer Waterways experiment Station \\ ATTN: CEWES-GP-Q (Mr. Randy C. Ahlrich) \\ 3909 Halls Ferry Road \\ Vicksburg, MS 39180-6199 \\ Telephone: 601-634-3367 \\ Facsimile: 601-634-3020 \\ US Army Engineering and Housing Support Center: \\ Commander \\ US Army Engineering and Housing Support Center \\ ATTN: CEHSC-FB-P (Mr. Joe Sicuranza) \\ Fort Belvoir, VA 22060-5516 \\ Telephone: 703-704-1575/1576 \\ Facsimile: 703-704-1610 \\ Demonstration Site (Fort Sill): \\ Directorate of Engineering and Housing \\ ATTN: ATZR-EED (Mr. Leo Horn) \\ Building 1950 \\ Fort Sill, OK 73503-5100 \\ Telephone: 405-351-4250 \\ Directorate of Engineering and Housing \\ ATTN: ATZJ-EHE-D (Mr. Gary Bowling) \\ Fort Jackson, SC 29207-5655 \\ Telephone: 803-751-4819
}




\section{Description of Asphalt-Rubber and Geotextile Interlayers}

One of the shortcomings of AC overlays is the eventual occurrence of reflective cracking. Reflective cracks are fractures in the overlay which result from movement of cracks and joints in the underlying pavement layers. This development of cracks is generally identical to that in the pavement overlaid. Without some form of prevention or reduction of these reflective cracks, early deterioration of an asphalt overlay occurs.

Methods for reducing reflective cracks in asphalt overlays have been tested in the field since the early 1930's and in the laboratory for 20 years. One method that has been successful in retarding and preventing reflective cracks in overlays covering both PCC and AC pavements is a stress-relieving interlayer. The stress-relieving interlayer can be an asphalt-rubber or geotextile interlayer. Both of these techniques have been successful in reducing reflective cracks.

The asphalt rubber interlayer consists of a layer of asphalt rubber covered with a coarse aggregate material. The asphalt rubber interlayer is constructed using bituminous surface treatment procedures. The asphalt rubber material is sprayed on the prepared surface and immediately covered with the aggregate material. This interlayer is not effective on PCC pavements and should not be used.

Geotextile interlayers consist of various synthetic fabrics and waterproofing membranes that are used to rehabilitate both PCC and AC pavements. The synthetic fabrics are manufactured by either a woven or nonwoven process consisting of polypropylene, polyester, nylon, and glass materials. Nonwoven fabrics are generally used to rehabilitate existing asphalt pavements. The waterproofing membrane interlayer consists of a woven or nonwoven fabric embedded in a layer of self-adhesive rubberized asphalt. These membranes are generally used on PCC pavements. A geotextile interlayer fact sheet is in Appendix C. 


\section{Application}

The asphalt-rubber and geotextile interlayers are used to prevent and reduce reflective cracks and to act as a waterproofing barrier when rehabilitating AC and PCC pavements with an asphalt overlay. These interlayers are recommended for structurally sound AC and PCC pavements that are to be overlaid. The existing pavement surface should be relatively smooth and should have negligible movement under traffic. These interlayers are best suited for rehabilitation projects located in mild, dry climates. Applications in cold climates have had less than satisfactory results.

\section{Limitations/Disadvantages}

The asphalt-rubber and geotextile interlayers should not be considered in all asphalt overlay projects. These rehabilitation techniques cannot be used to rehabilitate structurally unsound AC and PCC pavements. Existing AC pavements that exhibit alligator cracking or other evidence of weak subgrades and base courses have to be repaired prior to applying these interlayers. PCC pavements that have shattered or failed must be repaired.

Pavements that have excessive movements greater than 0.008 in. at cracks and joints should not be rehabilitated with asphalt-rubber or geotextile interlayers. AC and PCC pavements that have large vertical and horizontal movements caused by traffic loads and changes in moisture or temperature will not be good candidates for these rehabilitation techniques.

These techniques should not be considered in cold climates due to excessive movements in the underlying pavement caused by extreme temperatures. Specific guidance on the use of these interlayers is detailed in Appendix B.

\section{FEAP Demonstration/Implementation Sites}

In FY 85, an asphalt-rubber and geotextile interlayer demonstration was conducted on Geronimo Road at Fort Sill, Oklahoma. Geronimo Road is a twolane roadway that serves a residential area with moderate to heavy daily traffic. Prior to the demonstration, the existing AC pavement contained an extensive amount of transverse and longitudinal cracks. The resurfacing of 
this roadway involved using two stress-relieving interlayers, asphalt rubber and geotextile fabric, with a 2 -inch asphalt concrete (AC) overlay. This rehabilitation technique was implemented to reduce or prevent reflective cracks in the AC overlay. The southern portion of Geronimo Road between Post Road and Honeycutt Road was resurfaced using a nonwoven geotextile fabric produced by Phillips Fiber Corporation (Petromat). The geotextile fabric was installed with no problems using mechanical laydown equipment. This portion of Geronimo Road is performing extremely well to date.

The condition of the AC surface after 4 years of service was excellent. Only two transverse cracks have developed in the geotextile fabric interlayer section. These cracks were 5 to 6 feet long and $1 / 4$ inch wide. Longitudinal reflective cracks have developed over the face of the concrete curb and gutter. Approximately 20 to 30 percent of the joint between the curb and gutter and the existing $\mathrm{AC}$ pavement have reflected through the new AC overlay. Random low severity bleeding has also occurred in this portion of Geronimo Road. These bleeding areas were primarily located where the asphalt distributor stopped and started.

The northern portion of Geronimo Road between Honeycutt Road and Sheridan Road was resurfaced using an asphalt-rubber interlayer. The asphalt-rubber interlayer, sometimes known as SAMI, was placed using standard surface treatment procedures. The condition of the pavement in the northern portion of Geronimo Road was very good. Fourteen small transverse cracks have developed and were located across the centerline of the pavement. These cracks were randomly spaced every 30 to 50 feet and are 3 to 5 feet long. These reflective transverse cracks range in width from hairline to $1 / 4$ inch. Random low-severity bleeding areas have also occurred in this portion of Geronimo Road. Longitudinal cracking in the shoulders has occurred. These cracks can be attributed to pavement structural failure.

The overall condition of Geronimo Road in August 1990 was from good to excellent. The isolated bleeding areas have not caused a problem, and the asphalt material on the pavement surface was not tacky even when the air temperature was above 100 degrees $\mathrm{F}$. Both interlayers have resulted in an amount of reflective cracking judged to be less than that which would have occurred without them. The geotextile fabric was the most effective of the two interlayers. The only maintenance or repair work that has been conducted 
on this roadway has occurred at the intersection of Post Road. A 15-foot strip of asphalt concrete material was replaced because of irregular surface smoothness. No other maintenance has been conducted on Geronimo Road, but all adjacent streets in the residential area have been sealed during the period. Personnel at Fort Sill were very satisfied with the performance of the asphalt-rubber and geotextile fabric interlayers.

In FY 86, a geotextile interlayer demonstration was conducted on Hampton Parkway at Fort Jackson, South Carolina. Hampton Parkway is a four-lane divided roadway with eight crossover streets. The northwest lanes (downhill) provide access to administration buildings, housing facilities, and mess halls for trainee personnel. The southeast lanes (uphill) provide access to motorpools and the outer ranges. The traffic is very heavy on this roadway and varies from personal vehicles to heavy trucks.

Prior to the FEAP demonstration, Hampton Parkway was structurally sound, but in need of pavement maintenance and rehabilitation. The existing AC surface was worn and weathered with the entire surface containing polished aggregate. The existing pavement contained an extensive amount of medium to severe transverse and longitudinal cracks. The rehabilitation of Hampton Parkway involved cold milling, applying asphalt cement, placing a geotextile fabric, and overlaying with AC. The existing AC pavement was cold milled 1-1/2 inches. A nonwoven geotextile fabric manufactured by Phillips Fiber Corporation (Petromat) was placed on the milled surface after the application of asphalt cement. The resurfacing of Hampton Parkway was completed by placing 2 inches of $\mathrm{AC}$.

The condition of the AC surface after 4 years of service was very good. The southeast lanes have both random areas of bleeding and low severity transverse cracking. The bleeding areas are primarily located where the asphalt distributor stopped and started spraying. The reflective cracks that have developed were very fine ( $1 / 16$ to $1 / 8$ inch wide) and spaced 30 to 50 feet apart. A small section, approximately 150 feet long, has begun to deform and rut. This area of Hampton Parkway was reconstructed during the demonstration because of drainage problems and pavement failure. It appears that the pavement structure was still structurally unsound and will continue to deteriorate until the drainage pattern adjacent to the roadway is corrected. The northwest lanes of Hampton Parkway were also in good 
condition. The transverse cracks in the upper portion of the northwest lanes were more frequent ( 15 to 30 feet apart) and wider ( $1 / 8$ to $1 / 4$ inch wide).

The overall condition of the pavement on Hampton Parkway in August 1990 was excellent. No maintenance or repairs have been conducted on this pavement since the demonstration. The geotextile fabric interlayer has reduced and retarded reflective cracks in the AC overlay. Personnel at Fort Jackson were satisfied with the performance of the demonstration project.

\section{Life-Cycle Costs/Benefits}

Based on the demonstration projects, the simple payback in using asphalt rubber and geotextile interlayers is 3 to 4 years. The additional cost of the geotextile interlayer is between $\$ 0.25$ and $\$ 1.00$ per square yard, and the additional cost of the asphalt-rubber interlayer is between $\$ 1.00$ and $\$ 2.00$ per square yard. By using this technology, the service life of pavements can be extended 3 to 7 years which is a 20 to 40 percent increase in service life. The annual maintenance savings, as computed for a small-to-average size paving project, is 19.5 percent. This includes amortizing the construction costs over the life of the pavement.

The use of these interlayers with AC overlays will help reduce reflective cracks which lengthen the pavement life and decrease maintenance. These interlayers also prevent surface water from penetrating into the base course and subgrade and causing pavement structural failures. The cost savings will be noticed in man-hours (time) and the amount of material needed to maintain the roadway. The use of these interlayers can provide a pavement with many years of maintenance-free service. 


\section{PART III: ACQUISITION/PROCUREMENT}

\section{Potential Funding Sources}

Typically, installations fund the implementation of pavements and railroads technologies out of their annual budgets. However, the annual budget is always underfunded and normally the pavements and railroads projects just do not compete well with other high visibility/high interest type projects. As a result, it is in your best interest to seek all of the funds possible from other sources when the project merits the action. Listed below are some sources commonly pursued to fund projects.

a. Productivity program. See AR 5-4, Department of the Army Productivity Improvement Program for guidance to determine if the project qualifies for this type of funding.

b. Facilities Engineering Applications Program (FEAP). In the past, a number of pavement and railroad maintenance projects located at various installations were funded with FEAP demonstration funds. At that time, emphasis was placed on demonstrating new technologies to the Directorate of Engineering and Housing (DEH) community. Now that these technologies have been demonstrated, the installations will be responsible for funding their projects through other sources. However, emphasis concerning the direction of FEAP may change in the future; therefore, don't rule out FEAP as a source of funding.

c. Special programs. Examples of these are as follows:

(1) FORSCOM mobilization plan which may include rehabilitation or enlargement of parking areas and the reinforcement of bridges.

(2) Safety program which may include the repair of unsafe/ deteriorated railroads at crossings and in ammunition storage areas.

(3) Security upgrade which may include the repair or enlargement of fencing.

d. Reimbursable customer. Examples of this source are roads to special function areas such as family housing or schools and airfield pavements required to support logistical operations.

e. Special requests from MACOMS.

f. Year end funds. This type funding should be coordinated with the MACOMS to ensure that the funds will not be lost after a contract is advertised. 
g. Operations and Maintenance Army. These are the normal funds used for funding pavement and railroad projects.

\section{Technology Components and Sources}

Components of these technologies which must be procured to rehabilitate an AC or PCC pavement with the asphalt-rubber and geotextile interlayers are pavement preparation, application of interlayer, and AC overlay. A paving contractor is required to perform conventional pavement preparation and AC placement. A separate contractor may be required to place the asphalt-rubber or geotextile interlayer but this is unlikely. Contractors with previous experience involving placing these interlayers are recommended but not required.

All of the items used in the application of the asphalt-rubber and geotextile interlayers are conventional paving equipment. The procedures used in constructing these interlayers are common practice and are known throughout the paving industry.

\section{Procurement Documents}

A standard Corps of Engineers Guide Specification (CEGS) for the application of asphalt-rubber or geotextile interlayers is not available. A draft version of each procedure has been written but not officially published. An Engineer Technical Letter, ETL 1110-1-129, "Use of Engineering Fabrics and Asphalt-Rubber Interlayers to Minimize Reflective Cracking in Pavements," has been published and provides guidance on the use of these interlayers (Appendix B). A standard CEGS should be used for the AC overlay. The typical specifications for AC are CEGS 02551, "Bituminous Paving for Roads, Streets, and Open Storage Areas" and CEGS 02556, "Bituminous Intermediate and Wearing Courses (Heavy-Duty Pavements). State specifications can be used if a high-quality AC is specified.

The construction specification for projects involving an asphalt-rubber or geotextile interlayer will be site-specific and should meet the needs of the installation. The contract specifications will need to be modified and 
developed by in-house personnel. Examples of contract specifications used in FEAP demonstrations are found in Appendix D.

\section{Procurement Scheduling}

Normal construction contract schedules should be established that would allow adequate design and plan preparation time; design, review and approval; contract preparation; advertising and award; and construction time. A typical pavement project is designed 1 to 2 years before it is constructed; however, relatively small projects that require limited plans and specifications can be prepared and ready to go within a few months. 


\section{Initial Implementation}

\section{Equipment}

Standard paving equipment is used to construct asphalt-rubber and geotextile interlayers rehabilitation projects. Conventional asphalt paving construction equipment is used to prepare the pavement surface and to place the AC overlay. An asphalt distributor capable of spraying asphalt cement or asphalt-rubber materials is required along with equipment capable of spreading cover aggregate at a uniform rate. Mechanical fabric laydown equipment may also be needed when applying geotextile interlayers. This laydown equipment is required to place the fabric on the existing pavement without wrinkles.

\section{Material}

The AC material recommended for use with asphalt-rubber and geotextile interlayers is a standard dense-graded surface course asphalt mixture. The AC material should meet the requirements of CEGS 02551, CEGS 02556, or a highquality state highway specification.

The thickness of the asphalt overlay depends on the condition of the existing pavement surface and structure, the amount and type of traffic, and the geographic location and climate. The overlay thickness should always ensure that the new pavement structure will be structurally adequate. The minimum recommended overlay thicknesses are given in Appendix B.

Geotextile interlayers are used in two different capacities, full-width and strip methods. The full-width method generally uses a nonwoven material and is recommended for rehabilitating AC pavements. Properties required of nonwoven fabrics are listed in Table 1 . The strip method is used primarily on PCC pavements and involves placing 12- to 24-inch wide strip directly on the cracks and joints. Properties required for geotextile-membrane strips are listed in Table 2.

The asphalt-rubber material should be blended to produce a homogenous mixture that can be sprayed uniformly with an asphalt distributor. The asphalt-rubber blend will be site-specific depending on location, type of rubber, and type of asphalt cement. Manufacturer's recommendations should be followed. Examples are listed in Appendix D. 
Table 1

Property Requirements of Nonwoven Geotextiles

\begin{tabular}{lcc}
\hline \multicolumn{1}{c}{ Property } & Requirements & Test Method \\
\cline { 2 - 3 } $\begin{array}{l}\text { Breaking load, pounds/inch } \\
\text { of width }\end{array}$ & 80 minimum & ASTM D 4632 \\
$\begin{array}{l}\text { Elongation-at-break, percent } \\
\begin{array}{l}\text { Asphalt retention, gallons } \\
\text { per square yard }\end{array}\end{array}$ & 50 minimum & ASTM D 4632 \\
$\begin{array}{l}\text { Melting point, degrees } \\
\text { Fahrenheit }\end{array}$ & 0.2 minimum & Appendix D-3 \\
$\begin{array}{l}\text { Weight, ounce per square } \\
\text { yard }\end{array}$ & 325 minimum & ASTM D 276 \\
& $3-9$ & ASTM D 3776 \\
\end{tabular}

Table 2

Property Requirements for Geotextile-Membrane Strips

\begin{tabular}{|c|c|c|}
\hline Property & Requirements & Test Method \\
\hline $\begin{array}{l}\text { Permeance--perms } \\
\text { (grains square feet } 1 \text { hour } \\
1 \text { in HG) }\end{array}$ & 0.10 maximum & $\begin{array}{l}\text { ASTM E } 96 \\
\text { Method B }\end{array}$ \\
\hline $\begin{array}{l}\text { Tensile strength, pounds per } \\
\text { inch }\end{array}$ & 50 minimum & $\begin{array}{l}\text { ASTM D } 882 \\
\text { (line grips) }\end{array}$ \\
\hline $\begin{array}{l}\text { Puncture resistance, pounds } \\
\text { (geotextile) }\end{array}$ & 200 minimum & ASTM E 154 \\
\hline $\begin{array}{l}\text { Pliability, } 1 / 4-\text { inch mandrel } \\
180 \text { degree bend at } \\
-15 \text { degrees } F\end{array}$ & No cracks & ASTM D 146 \\
\hline
\end{tabular}




\section{$\underline{\text { Personnel }}$}

Regular paving construction personnel are used in an asphalt-rubber and geotextile interlayer project. In the demonstration projects, a paving contractor performed all of the construction including the interlayers. In both demonstrations, manufacturer's representatives were on site to provide guidance during installation of the interlayers. Installation personnel provided design, inspection, and contract administration.

\section{Procedure}

Given the need to rehabilitate an AC or PCC pavement with an asphalt overlay, the procedure has three major steps:

a. Decide if reflective cracks need to be prevented or reduced.

b. Establish a cost-effective solution for minimizing reflective cracks (consistent with "Limitations/Disadvantages" on page 6) from one of the three options listed:

(1) Repair existing pavement by using recycling techniques.

(2) Crack and seat PCC pavement prior to asphalt overlay.

(3) Install asphalt-rubber or geotextile interlayers prior to asphalt overlay.

c. If the interlayer option is selected, the design of the pavement rehabilitation must be prepared. Factors to be considered include determining existing pavement parameters; thickness, types of cracks, causes of cracks, size of cracks, drainage, and subgrade strength. Specifics concerning the asphalt-rubber and geotextile interlayers will have to be specified; application rates, type of geotextile, and overlay thickness.

The recommended construction procedures will be site-specific and vary with the conditions of the existing pavement. The following are general recommendations for construction procedures for installing interlayers:

a. Remove and repair all structurally unsound pavements.

b. Fill cracks and joints larger than $1 / 4$ inch with proper sealing material.

c. Establish proper drainage to prevent weakening of pavement structure.

d. Clean pavement surface of all loose debris by brooming.

e. Place interlayer according to proper specifications.

f. Place a conventional asphalt overlay of adequate thickness. 


\section{Operation and Maintenance}

Operation and maintenance of an asphalt-rubber and geotextile interlayer rehabilitation project are no different than that of any conventional AC overlay. Past experience with these rehabilitation techniques have indicated that the pavement service life is increased and that maintenance is delayed and reduced. The performance of an asphalt-rubber or geotextile interlayer project will depend upon a combination of factors including pavement structural strength, overlay thickness, local climatic conditions, and the amount and type of traffic.

\section{Service and Support Requirements}

No special services or support are required to implement or maintain this technology.

\section{Performance Monitoring}

Installation personnel can monitor and measure the performance of the asphalt-rubber and geotextile interlayers by conducting periodic inspections of the surface of the asphalt overlay for signs of distress (cracking, bleeding, rutting, etc.). Unusual traffic and climatic conditions could adversely affect performance and should be noted. The asphalt overlay should be considered to be performing satisfactorily, provided that reflective cracks have been retarded and reduced. Poor performance will exhibit moderate to severe reflective cracking in the new asphalt overlay. 
APPENDIX A: AD FLIER 


\section{Asphalt-Rubber \& Geotextile Interlayers Relieve Stresses on New Pavement Surface}

\section{Description of Technology}

Asphalt overlays on deteriorated pavements usually sustain reflective cracking over time. Cracks and joints from the underlying pavement propagate up through the new overlay and cause early deterioration of the pavement by raveling and spalling. The reflective cracks then require maintenance to prevent further damage to the pavement.

New materials and improved construction techniques led to the development of asphalt-rubber and geotextile interlayer materials that are placed between the old wearing surface of a pavement and a new overlay surface. These stress-relieving interlayers substantially reduce the amount of reflective cracking in the new wearing surface.

The interlayers can be used in an asphalt overlay of either asphalt concrete or Portland cement concrete. Interlayers are suitable for use in pavement overlays of residential streets, primary user roads, parking lots, and most other types of pavements. Interlayers perform very well in warm climates, but have met with less success in cold climates.

\section{Details of Demonstration}

The U.S. Army Engineer Waterways Experiment Station (WES) demonstrated these interlayers at Fort Sill, OK, in FY85 and Fort Jackson, SC, in FY86. The pavements at both installations had exceeded the service life (15 years), were extensively cracked and had begun raveling, and were already scheduled for much needed rehabilitation. Neither installation had intended to use an interlayer in the overlay. Without the interlayer, severe reflective cracking of the new overlay surface probably would have occurred within 6 to 18 months after rehabilitation.

At Fort Sill, geotextile and asphalt-rubber interlayers were placed before an asphalt concrete overlay was applied. At Fort Jackson, the existing surface was cold-milled before an engineering fabric interlayer and overlay were placed. Both projects were inspected 1 year after rehabilitation. Reflective cracking had been reduced at both sites by 80 to 90 percent over that normally expected in the same timeframe. Some reflective cracking had occurred in the pavement overlay at intersections.

\section{Cost and Benefits}

Material costs for the demonstrations averaged about $\$ 1 /$ square yard for geotextile and $\$ 2.25 /$ square yard for asphalt rubber. These prices will fluctuate, depending on the product and the local market. Expect to pay $\$ 0.50$ to $\$ 1.25 /$ square yard for geotextiles; asphalt rubber overlays range from $\$ 1.50$ to $\$ 2.50 /$ square yard.

The use of asphalt-rubber and/or geotextile interlayers in pavement overlays will definitely reduce reflective cracking, which will extend average service life of pavements by 3 to 7 years. The annual maintenance savings, as computed for a small to average size pavement project, is approximately 19.5 percent. With over 60,000 lane miles of pavements and around $\$ 70$ million spent annually on pavement maintenance and repair, the Army could save hundreds of thousands of dollars by using interlayers where feasible in overlay projects.

The interlayers also prevent surface water from penetrating into the base course and subgrade and causing water-related maintenance problems.

\section{Procurement}

Both interlayer materials are widely available on the market from industrial manufacturers. More information on this technology may be found in WES report GL86-34, Evaluation of Asphalt Rubber and Geotextile Fabrics as Pavement Interlayers. Draft Technical Manual 5-800-08, Engineering Use of Geotextiles, is being reviewed at Army Headquarters.

\section{Points of Contact}

Randy Ahlrich, WES, 3909 Halls Ferry Road, Vicksburg, MS 39180-6199, COMM 601-634-3367. Ken Gregg, U.S. Army Engineering and Housing Support Center (USAEHSC), Building 358, Fort Belvoir, VA 22060-5516, COMM 703-355-3582. 
APPENDIX B: ENGINEER TECHNICAL LETTER 
DAEN-ECE - G

Engineer Technical

Letter 1110-1-129
DEPARTMENT OF THE ARMY

U.S. Army Corps of Engineers

Washington, D.C. 20314-1000

ETL $1110-1-129$

15 December 1985

\section{Engineering and Construction \\ USE OF ENGINEERING FABRICS AND ASPHALT \\ RUBBER INTERLAYERS TO MINIMIZE REFLECTIVE CRACKING IN PAVEMENTS}

1. Purpose. This letter provides guidance for minimizing reflective cracking of asphaltic concrete pavements.

2. Applicability. This letter applies to all HQUSACE/OCE elements and field operating activities (FOA) having military and/or civil works construction responsibility.

3. References. (See Enclosure 3 ).

4. Discussion.

a. Engineering fabrics and asphalt rubber have been used by various government agencies in an attempt to minimize the detrimental effects of reflective cracking. While performance has varied widely, it has been observed that these materials generally provide satisfactory performance in warm climates and unsatisfactory performance in cold climates. This letter provides recommended guidance concerning locations in which satisfactory performance can be expected with asphalt rubber and engineering fabrics based on results from recent studies at the Waterways Experiment Station (WES) including data from other sources, mainly Federal Highway Administration. Report of the WES studies is currently at the publishers and will be distributed in the near future. Some references from the report are provided with this ETL.

b. The studies involved evaluating the performance of a number of projects that had been constructed and observed over a period of years. After the results were obtained, it became apparent that performance was a function of two important parameters--overlay thickness and freezing index. The freezing index can be computed from temperature records for a given area using the guidance provided in TM 5-818-2, Pavement Design for Seasonal Frost Conditions.

5. Action to be Taken.

a. Figure 1 shows three climatic areas of the continental United States. Area I outlines an area with a freezing index below zero; Area II shows the area with a freezing index between zero and five hundred; and Area III shows the area having a freezing index greater than five hundred. If different local freezing indexes exist than shown on figure 1, the existing should be used. 
b. Based on evaluation of current materials the following guidance is provided for use of engineering fabrics or asphalt rubber.

(1) When overlaying asphaltic concrete, engineering fabric or asphalt rubber can be used in Areas I and II. A 2-inch minimum overlay is required in Area I, and a minimum 3 -inch overlay (at least two layers) is required in Area II. Neither asphalt rubber nor engineering fabric should be used when overlaying asphaltic concrete in Area III.

(2) When overlaying portland-cement concrete (PCC), asphalt rubber is not effective as an interlayer and, therefore, should not be used.

Engineering fabric is effective when used in Areas I and II, but should not be used in Area III. An engineering fabric strip is used to cover all joints when overlaying PCC to minimize the material costs. A 4-inch minimum overlay is required in Areas I and II to ensure satisfactory performance.

(3) Recommended properties of fabrics are shown in table 1.

(4) When local experience has shown satisfactory performance different from that described in the above guidance, local criteria should be used.

(5) Performance of new materials used in Area III will be monitored and guidance will be provided on favorable materials as they develop.

(6) The guidance in this ETL will be incorporated in the appropriate road and airfield manuals.

6. Implementation. This letter will have routine application as defined in paragraph 6c, ER 1110-345-100. This letter will have application to all future civil works projects, except where local requirements govern otherwise.

FOR THE COMMANDER:

3 Encls

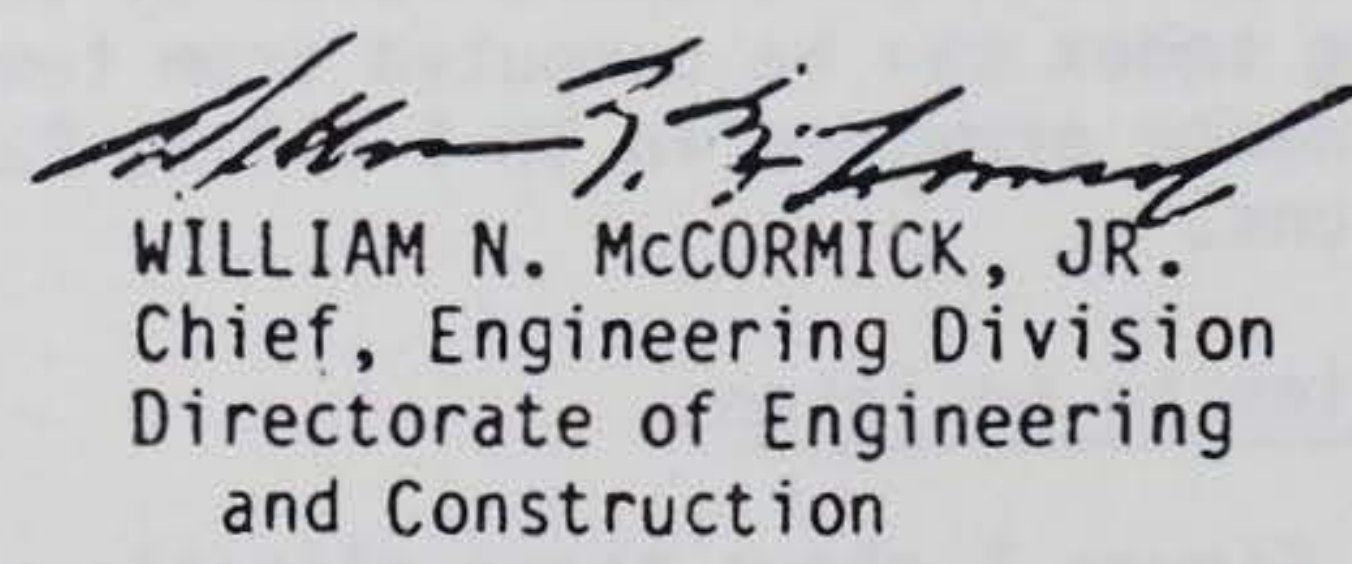




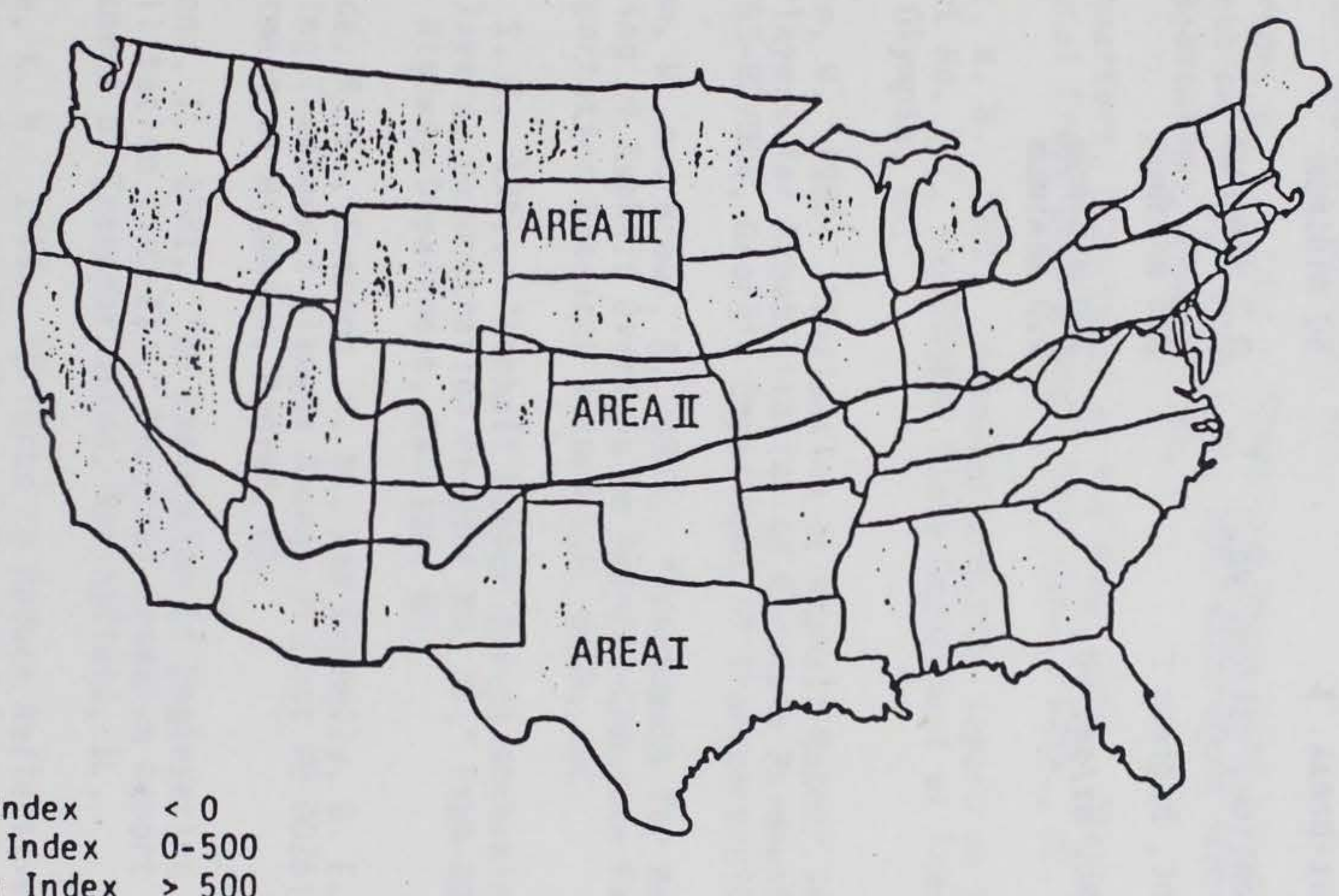

Area II Freezing Index $0-500$

Area III Freezing Index > 500

Figure 1. Three climatic areas of the continental United States 
ETL $1110-1-129$

15 Dec 85

Table 1: Recommended Properties of Geotextiles Used to Reduce Reflective Cracking

\author{
Property \\ Tensile Strength, Ibs. \\ Elongation-at-Break, \% \\ Asphalt retention, gal/sq. yd. \\ Melting point, Degrees $F$ \\ Fabric weight, 0z/sq. yd.
}

Requirement

80 minimum

50 minimum

0.2 minimum

325 minimum

3.0 minimum

9.0 maximum
Test Method

ASTM D 1682

ASTM D 1682

TDHPT 3099

ASTM D 276

ASTM D 1910 


\section{ETL $1110-1-129$}

15 Dec 85

\section{REFERENCES}

1. Anderson, K. W. 1983. "Rubber-Asphalt Binder Stress-Absorbing Membrane Interlayer," Report No. 178, Washington State Department of Transportation, Olympia, WA.

2. Anderson, K. W. 1983. "Rubber-Asphalt Binder Stress Absorbing Membrane Interlayer," Report No. 187, Washington State Department of Transportation, 01 ympia, WA.

3. Anderson, K. W. 1983. "SAMI and Heavy Duty Bituthene Reflection Crack Prevention Study," Report No. 186, Washington State Department of Transportation, Olympia, WA.

4. Headquarters, Department of the Army 1985. "Pavement Design for Seasonal Frost Conditions," TM 5-818-2, WASH., DC.

5. Gietz, R. H. 1981. "Post-Construction Report on Fabric Reinforcement," Report No. 172, Washington State Department of Transportation, Report No. 172, 01 ympia, WA.

6. Gulden, W. 1982. "Evaluation of Asphalt-Rubber Seal Coats and Interlayers for Rehabilitation of Flexible Pavements," Report No. FHWA/GS-82/004, Georgia Department of Transportation, Atlanta, GA.

7. Gulden, W. and Brown, 'D. 1983. "Treatments for Reduction of Reflective Cracking of Asphalt Overlays on Jointed-Concrete Pavements in Georgia," Transportation Research Record 916, WASH., DC.

8. Kidd, S. Q. 1981. "Asphalt Rubber Stress Absorbing Membrane Interlayers, Demonstration Project No. 37," FHWA-DD-37-17, Mississippi State Highway Department, Jackson, MS.

9. Laforce, R. F., Swanson, H. N., and Donnelly, D. E. 1980. "Reflection Cracking Treatments Alameda Avenue Project MU 0026(2)," Colorado Department of Highways, Denver, CO.

10. Mascunna, I. 1981. "An Evaluation of Engineering Fabric in Pavement Rehabilitation (IHD-21)," Physical Research Report No. 88, Illinois Department of Transportation, Springfield, IL.

11. McGhee, K. H. 1975. "Efforts to Reduce Reflective Cracking of Bituminous Concrete Overlays of Portland Cement Concrete Pavements," Virginia Highway and Transportation Research Council, Charlottesville, VA.

12. Morris, G. R. and MCDonald, C. H. "Asphalt-Rubber Stress Absorbing Membranes: Field Performance and State of the Art," Phoenix, AZ.

13. Sherman, G. 1982. "Minimizing Reflection Cracking of Pavement Overlays," Transportation Research Board, WASH., DC. 
ETL $1110-1-129$

15 Dec 85

14. Swanson, H. N., LaForce, R. F., and Donnelly, D. E. 1980. "Reflection Cracking Evaluation Kannah Creek, Colorado Project FC 050-1(8)," Colorado Department of Highways, Denver, Co.

15. Vedros, P. J., Jr. 1981. "Evaluation of Membrane Interlayers for Prevention of Crack Reflection in Thin Overlays," Miscellaneous Paper GL-81-8, US Army Engineer Waterways Experiment Station, Vicksburg, MS .

16. Way, G. B. 1976. "Prevention of Reflective Cracking in Arizona Minnetonka-East (A Case Study)," Arizona Department of Transportation, Phoenix, AZ.

17. Way, G. B. 1979. "Prevention of Reflective Cracking Minnetonka-East (1979 Addendum Report)," Arizona Department of Transportation, Phoenix, AZ.

Zazr Teeh Levters (EIL) Action: op?k?

Route:

1. Erec

3. 0-?\&?

3. ja fety

4. PYSO
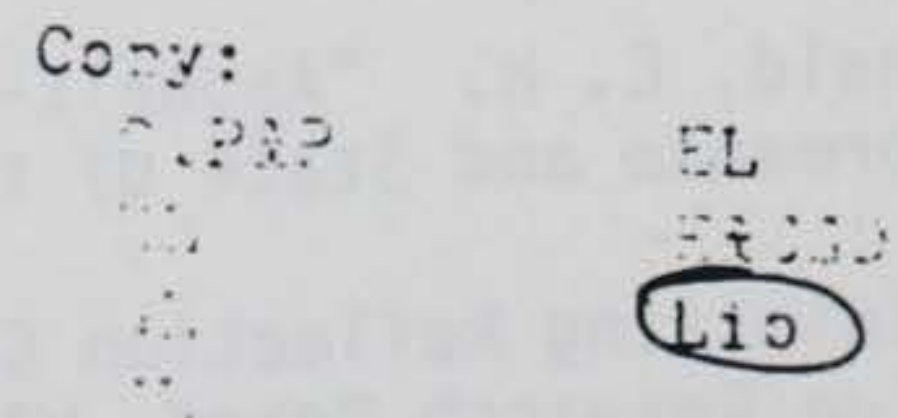
APPENDIX C: GEOTEXTILE INTERLAYER FACT SHEET 


\section{DESCRIPTION:}

Geotextile interlayers are used with an asphalt concrete overlay to retard or prevent reflection cracks from the underlying pavement. A geotextile interlayer absorbs or relieves the stress exerted on the overlay by the cracks and joints in the existing pavement. These interlayers consist of various synthetic fabrics and water-proofing membranes that are applied to both asphalt concrete (AC) and portland cement concrete (PCC) pavements. The synthetic fabrics are manufactured by either a woven or nonwoven process consisting of polypropylene, polyester, nylon or glass materials. The waterproofing membrane consists of a woven or nonwoven fabric embedded in a thick layer of self adhesive rubberized asphalt.

\section{AREAS OF APPLICATION:}

Geotextile interlayers are used in rehabilitating both AC and PCC pavements. This technique is used to retard and reduce the reflective cracks and joints that propagate through the new AC overlay. The geotextile interlayer also seals the existing pavement and performs as a moisture barrier to prevent surface water from entering the base and subgrade resulting in reduced pavement strength.

\section{PHYSIOGRAPHIC FACTORS:}

A geotextile interlayer should be applied to structurally sound AC and PCC pavements that contain transverse and longitudinal cracks. The existing pavement should be relatively smooth and should have negligible movement under loads. Structural deficient pavement should be repaired prior to application of geotextile interlayer.

The geographic location and climate of the project site have an important part in determining whether or not geotextiles can be successfully used in pavement rehabilitation. Geotextiles are successful in preventing and retarding reflective cracks in mild dry climates while geotextiles in cold climates have not been as successful.

\section{DISCUSSION AND RECOMMENDATIONS:}

Geotextile interlayers can be used in rehabilitating asphalt concrete and portland cement concrete pavement. Interlayers perform the same function for both pavements but use various types of geotextiles and overlay thicknesses. For all interlayer applications, the pavement surface should be cleaned of all debris and also joints and cracks larger than $1 / 8$ inch in width should be sealed.

\section{$\underline{\text { AC }} \underline{\text { Pavements }}$}

a. General Geotextile interlayers can be applied directly on the existing surface or placed on an asphalt concrete leveling surface if the existing pavement is uneven and severly cracked. Fall-width nonwoven fabrics are recommended for reflective crack treatment of AC pavements. The geotextile must be strong enough to absorb the stress applied by the movement 
of cracks and be able to elongate with this movement. The geotextile must also be able to retain enough asphalt material to form a water tight barrier.

b. Overlay Thickness. The minimum recommended asphalt concrete overlay thickness is based on climatic conditions and geographic location. Areas of the continental United States with a mean air freezing index below zero require a minimum overlay of 2 inches while areas with a mean air freezing index between zero and five hundred require a minimum overlay of 3 inches. Geotextile interlayers should not be used in areas with a mean air freezing index greater than five hundred. AC overlay should always be increased to meet required structural requirements.

c. Construction. The construction techniques involved in placing geotextiles prior to an asphalt concrete overlay are critical. Before placing the geotextile, the existing pavement surface must be prepared and the asphalt sealant uniformly sprayed. The geotextile must be placed soon after the asphalt sealant is sprayed to insure proper bond. The asphalt concrete overlay should be placed over the geotextile as soon after placement of geotextile as possible.

d. Asphalt Sealant. The application rate should range from 0.20 to 0.40 gallon per square yard or as recommended by manufacturer. The amount of asphalt sealant will depend upon the asphalt retention properties of the geotextile and the porosity and surface texture of the existing surface. The application rate specified should be sufficient to bond the geotextile and the overlay to the existing pavement and to obtain a tight waterproof membrane.

e. Geotextile Installation. The geotextile should be placed with mechanical equipment immediately after the asphalt sealant has been applied and before the materials have cooled and lost tackiness. The geotextile should be aligned and carefully broomed to remove air bubbles and to insure intimate contact of the geotextile with the existing surface. Every effort should be made to lay the geotextile as smoothly as possible to avoid any wrinkling.

f. AC Overlay. The asphalt concrete overlay should be placed as close behind the geotextile laydown as possible. All movements by pavers and other vehicles on the geotextile should be kept to a minimum to avoid damage to the geotextile. The asphalt concrete material should conform to applicable specification requirements.

\section{$\underline{\text { PCC }} \underline{\text { Pavements }}$}

General. Geotextiles should be applied to PCC pavements that are structurally sound and have minimum slab movement. Geotextile interlayers are used in two different capacities, the full-width and strip methods. The fullwidth method involves sealing cracks and joints and placing an asphalt concrete leveling course prior to the placement of a nonwoven geotextile. The remainder of this application is identical to the geotextile interlayer for AC pavements. The strip method involves the sealing of cracks and joints but requires no leveling course. The single water proofing membrane strip, which are usually 12 to 24 inches wide, are placed after an application of a primer directly on the joints and cracks and overlaid with asphalt concrete. 
Overlay Thickness. The minimum overlay thickness of an asphalt concrete overlay for geotextile application on portland cement concrete pavements is 4 inches. Areas with a mean air freezing index below five hundred should use a minimum overlay of 4 inches. Geotextile interlayers are not recommended in areas with a mean air freezing index greater than five hundred.

Construction. The construction techniques involved in placing geotextiles prior to an asphalt concrete overlay are similar to the procedure outlined for AC pavements. The existing portland cement concrete pavement should be cleaned and stablized prior to installing a geotextile. In either application, the full-width or strip method, the geotextile must be installed in such a manner to insure a proper bond with the existing pavement. A conventional tack coat should be applied with the strip method to insure a good bond between the existing PCC pavement and the asphalt concrete overlay. The asphalt concrete overlay should be placed immediately after placement of the geotextile to avoid any damage to the geotextile.

SUMMARY:

A geotextile interlayer can be used as a pavement rehabilitation technique to retard and reduce reflective cracks and to seal the existing pavement from surface moisture; but it is not a "cure-all as a pavement maintenance tool. Good judgement must be used in selecting pavements for treatment and only structurally sound pavements should be selected. Consideration of climatic conditions and geographic location along with the asphalt concrete overlay thickness must be taken into account. Proper construction techniques must also be followed to insure a good performance of geotextile interlayers.

SPECIFIC REFERENCES:

Ahlrich, R. C., "Evaluation of Asphalt-Rubber and Engineering Fabrics as Pavement Interlayers", January 1985, Twenty-Second Paving and Transportation Conference.

GENERAL REFERENCES:

Jackson, R. D., "Use of Fabrics and Other Measures for Retarding Reflective Cracking of Asphaltic Concrete Overlays", Miscellaneous Paper GL-80-2, U.S. Army Engineer Waterways Experiment Station.

Sherman, G., "Minimizing Reflection Cracking of Pavement Overlays", September 1982, Transportation Research Board.

Vedros, P. J., Jr., "Evaluation of Membrane Interlayers for Prevention of Crack Reflection in Thin Overlays", Miscellaneous Paper GL-81-8, U. S. Army Engineer Waterways Experiment Station, October 1981. 
APPENDIX D: CONTRACT AND MANUFACTURER SPECIFICATIONS 


\section{INTERNATIONAL SURFACING, INC. GUIDE SPECIFICATION FOR} ASPHALT-RUBBER STRESS ABSORBING TREATMENT
(SAM or SAMI) for
HIGHWAYS, ROADS, STREETS and AIRPORTS.

Note: Aftached are "Notes to Engineer" which are referenced to by an asterisk ("). It is important that these notes be referred to when developing a specification from this guide for highway, road, street, and airport asphalt-rubber projects.

\section{SCOPE}

This specification covers the material, equipment, and construction procedures for a Stress Absorbing

\section{PREQUALIFICATION OF A NEW ASPHALT-RUBBER MATERIAL}

Prequalification of a new asphalt-rubber material or applicator may be requested at any time. Prequalification will be based on three controlled field applications evaluated after three years' performance under traffic. New asphaltrubber material that has been evaluated and prequalified by an agency recognized nationally may be prequalified by that agency upon disclosure of suitable evidence of successful performance. Notwithstanding other agency prequalification, this agency reserves the right to withhold prequalification pending the performance evaluation of local controlled field applications.

\section{MATERIALS}

\subsection{Asphait}

The grade of asphalt cement for the asphalt-rubber mixture shall be or which shall comply with the requirements of ___ . The grade selected shall be based on laboratory testing by the asphalt-rubber supplier, to insure compatibility with the granulated reclaimed rubber.

If indicated necessary by laboratory testing, an approved anti-stripping additive may be added to the asphalt cement up to 1.0 percent by weight of asphalt.

\subsection{Granulated Reclaimed Rubber}

The granulated reclaimed rubber used shall be produced primarily from the processing of automobile and truck tires. The rubber shall be produced by ambient temperature grinding processes only.

The gradation of the granulated reclaimed rubber when tested in accordance sith ASTM C-136 and using a 50 gram \pm 1 gram sample, shall meet the following requirements:

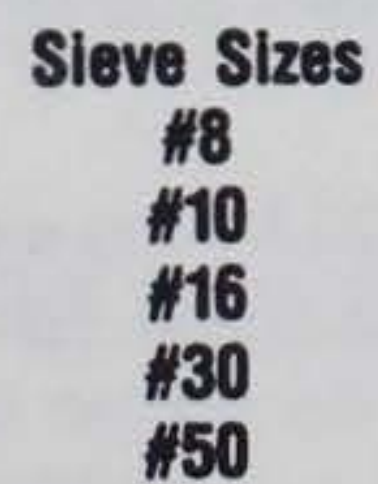

$$
\begin{gathered}
\text { Percent Passing } \\
100 \\
95=100 \\
40=60 \\
0=10 \\
0.5
\end{gathered}
$$

The use of rubber from multiple sources is acceptable provided that the overall blend of rubber meets the gradation requirements.

The individual granulated rubber particles, irrespective of diameter, shall not be greater in length than $3 / 16$ inch $(5 \mathrm{~mm})$. 
The granulated rubber shall have a specific gravity of $1.15 \pm 0.05$ and shall be free of loose fabric, wire and other contaminants except that up to 4 percent (by weight of rubber) calcium carbonate or talc may be added to prevent rubber particles from sticking together. The rubber shall be sufficiently dry so as to be free flowing and not produce a foaming problem when blended with the hot asphalt cement.

The granulated reclaimed rubber shall be accepted by certification from the rubber supplier.

\subsection{Diluent}

The diluent shall have the following properties:

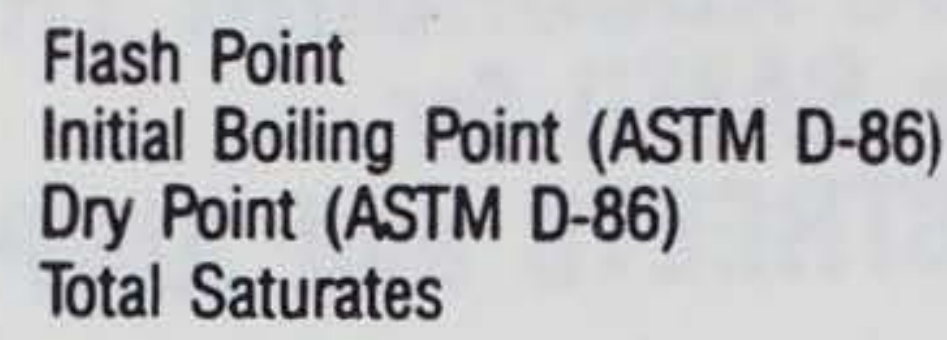

$130^{\circ} \mathrm{F}$ Minimum $340^{\circ} \mathrm{F}$ Minimum $390^{\circ}-415^{\circ} \mathrm{F}$

$85 \%$ Minimum

\subsection{Asphalt-Rubber}

The asphalt-rubber supplier shall furnish to the engineer a minimum of 10 days before the beginning of membrane placement, the asphalt-rubber mix formulation which shall contain the following information:

Asphalt Cement

Source of Asphalt Cement

Grade of Asphalt Cement

Percentage of Asphalt Cement by total weight of the asphalt-rubber mixture.

\section{Granulated Reclaimed Rubber}

Source of Granulated Rubber

Grade of Granulated Rubber

Percentage of Granulated Rubber by total weight of the asphalt-rubber mixture. each granulated rubber used.

If granulated rubber from more than one source is utilized the above information will be required for

Diluent

Source of Diluent

Grade of Diluent

Percentage of Diluent allowable by volume of the asphalt-rubber mixture.

\subsection{Cover aggregate} conforming to

Aggregate shall be composed of a clean and durable crushed rock, crushed gravel or crushed slag

Proposed aggregate samples shall be submitted to the asphalt-rubber supplier a minimum of 21 days prior to application, to test for aggregate stripping characteristics. The results shall be submitted to the engineer. Anti-strip will be included as a contingency bid item.

\section{EQUIPMENT}

\subsection{General}

The equipment used by the contractor shall include a self propelled rotary power broom or mobile pickup broom for pavement cleaning and excess cover material removal.

\subsection{Asphalt-Rubber Equipment}

follows:

All equipment utilized in the production and application of the asphalt-rubber shall be as described as

4.2.1 An asphalt heating tank with a hot oil heat transfer system or retort heating system capable of heating asphalt cement to the necessary temperature for blending with the granulated rubber. This unit shall be capable of heating a minimum of 3,000 gallons of asphalt cement.

4.2.2 An asphalt-rubber mechanical blender with a two stage continuous mixing process capable of producing a homogenous mixture of asphalt cement and granulated rubber, at the mix design specified ratios, as directed by the engineer. This unit shall be equipped with a granulated rubber feed system capable of supplying the asphalt cement feed system, as not to interrupt the continuity of the blending process. A separate asphalt cement feed pump and finished product pump are required. This unit shall have both an asphalt cement totalizing meter in galions and a flow rate meter in gallons per minute. 
4.2.3 A truck or trailer mounted self powered distributor truck equipped with a retort heating unit, and an internal mixing device capable of maintaining a uniform mixture of asphalt cement and granulated rubber. It shall be equipped with a full circulating spreader bar and a pumping system capable of applying asphalt-rubber material within \pm .05 gallons per square yard tolerance of the specified application rate and must give a uniform covering of the surface to be treated. The distributor shall have a boot board on the rear of the vehicle and a bootman shall accompany the distributor. The bootman shall ride in a position so that all spray bar tips are in full view and readily accessible for unplugging if a plugged tip should occur. The distributor shall also include a tachometer, pressure gauge, volume measuring device and a thermometer.

\subsection{Cover Material Spreader}

The cover material (chip) spreader shall be a self-propelled machine with an aggregate receiving hopper in the rear, belt conveyors to carry the aggregate to the front, and a spreading hopper equipped with a full-width distribution auger and spread roll. The spreader shall be in good mechanical condition and be capable of applying the cover material uniformly across the spread at the specified rate.

\subsection{Rolling Equipment}

A minimum of three operational self-propelled pneumatic-tired rollers shall be used for the required rolling of the cover material. The pneumatic-tired rollers shall carry a minimum loading of 3,000 pounds on each wheel and a minimum air pressure of 100 pounds per square inch in each tire.

\subsection{Hauling Equipment}

Trucks for hauling cover material shall be tailgate discharge and shall be equipped with a device to lock onto the hitch at the rear of the cover material spreader. Haul trucks shall also be compatible with the cover aggregate spreader so that the dump bed will not push down on the spreader when fully raised or have too short a bed which results in aggregate spillage while dumping into the receiving hopper.

\section{CONSTRUCTION}

\subsection{General}

For optimum performance it is recommended that holes and depressions in the old pavement surfacing should be repaired by patching and transverse and longitudinal cracks $3 / 8$ inch wide and above be repaired by cleaning and filling with an asphalt-rubber crack sealant.

Immediately prior to the application of the asphalt-rubber membrane, the surface shall be thoroughly cleaned in order to insure adequate adhesion of the asphalt-rubber to the pavement.

Due to the handling characteristics of asphalt-rubber, when radii and other irregular areas are to be sealed it is recommended that this be done with an RS or CRS chip seal emulsion or paving grade asphalt cement.

\subsection{Asphalt-Rubber Mixing and Reaction}

The percentage of granulated rubber shall be 23 percent plus or minus 3 percent by weight of total asphaltrubber mixture, the exact granulated rubber content shall be as determined by the mix design submitted by the asphaltrubber supplier. During membrane placement the granulated rubber percentage shall not fluctuate more than 1 percent by weight of total asphalt-rubber mixture.

The temperature of the asphalt cement shall be between 350 and $425^{\circ} \mathrm{F}$ at the addition of the granulated rubber. The asphalt and rubber shall be combined and mixed together in the asphalt-rubber blending unit and reacted in the distributor for a period of time as required by the engineer which shall be based on laboratory testing by the asphalt-rubber supplier. The temperature of the asphalt-rubber mixture shall be above $350^{\circ} \mathrm{F}$ during the reaction period.

After the reaction between asphalt cement and granulated rubber has occurred, the viscosity of the hot asphalt-rubber mixture may be adjusted for spraying and/or better "wetting" of the cover material by the addition of a diluent. The diluent shall comply with the requirements of Section 3.3 and shall not exceed 7.5 percent by volume of the hot asphalt-rubber mixture.

When a job delay occurs after full reaction, the asphalt-rubber may be allowed to cool. The asphalt-rubber shall be reheated slowly just prior to application but not to a temperature exceeding $350^{\circ}$. An additional quantity of diluent not exceeding 3 percent by volume of the hot asphalt-rubber mixture may be added after reheating. 


\subsection{Application of Asphalt-Rubber Material}

Placement of the asphalt-rubber membrane shall be made only under the following conditions:

1. The pavement surface temperature shall be $45^{\circ} \mathrm{F}$ and rising.

2. The pavement surface is clean and absolutely dry.

3. The wind conditions are not excessive.

4. All construction equipment such as asphalt-rubber distributor, cover material spreader, haul trucks with cover material, and rollers are in position and ready to commence membrane placement operations.

5. Rain is not imminent.

The asphalt-rubber mixture shall be applied at a temperature of $300^{\circ}$ to $350^{\circ} \mathrm{F}$ at a rate of Transverse joints shall be constructed by placing building paper across and over the end of the previous asphalt-rubber application. Once the spraying has progressed beyond the paper, the paper shall be removed immediately and disposed of as directed by the engineer. All longitudinal joints shall not exceed a four inch overlap.

\subsection{Application of Cover Material}

Cover material shall be applied immediately to the asphalt-rubber after spreading at a rate of * to pound per square yard.

At the time of application to the asphalt-rubber, cover material shall be surface dry so as to gain proper adhesion to the asphalt-rubber material.

\subsection{Rolling}

At least three operational pneumatic-tired rollers complying with the requirements of Section 4.4 shall be provided to accomplish the required embedment of the cover material. At some project locations or where production rates dictate, fewer rollers may be utilized as directed by the engineer. At no time shall there be less than two operational pneumatic tired rollers on a project.

Sufficient rollers shall be used for the initial rolling to cover the width of the aggregate spread with one pass. The first pass shall be made immediately behind the cover material spreader, and if the spreading is stopped for an extended period, the cover material spreader shall be moved ahead or off the site so that all cover material may be immediately rolled. Four complete passes with rollers shall be made with all rolling completed within one hour after the application of the cover material.

\subsection{Traffic Control}

Except when it is necessary that hauling equipment must travel on the newly applied membrane, traffic of all types must be kept off the membrane until it has had time to set properly. The speed of all hauling equipment shall not exceed 15 miles per hour when traveling over a membrane which is not adequately set. The minimum traffic free period shall not be less than one hour.

\subsection{Removing Loose Cover Material}

Sweeping can begin a minimum of one hour after membrane placement.

\subsection{Method of Measurement and Basis of Payment}

Dependent on agency preference the asphalt-rubber can be paid for per square foot, per square yard, per gallon, or per ton of mixture in-place, which includes asphalt cement, granulated reclaimed rubber and diluent.

Cover aggregate and a contingent bid item for an anti-strip agent should be allowed for in the bid schedule. 


\section{Section 1}

\section{NOTES TO ENGINEER}

For a Stress Absorbing Membrane, the first blank should read "Membrane". For a Stress Absorbing Membrane Interlayer, the blank should read "Membrane Interlayer".

\section{Section 3}

The first blanks will indicate the penetration or viscosity grades of asphalt cement specified. The second blank will indicate AASHTO M20, ASTM D946, AASHTO M226, ASTM D3381 or an appropriate local or state highway department specification.

Relative to the grades indicated, the following table provides recommendations for selection of the asphalt cements to be used in asphalt-rubber.

\begin{tabular}{ll} 
CLIMATE & \multicolumn{1}{c}{ AASHTO M226 } \\
ASTM D3381 \\
Cold & AC-2.5, AC-5 or AC-10 \\
& AR-1000 or AR-2000 \\
Moderate & AC-5 or AC-10 \\
Hot & AR-1000 or AR-2000 \\
& AC-10 or AC-20 \\
& AR-2000 or AR-4000
\end{tabular}

AASHTO M20

ASTM D946

$120-150$ or $200-300$

$85-100$ or $120-150$

$60-70$ or $85-100$

-The exact grade of asphalt cement shall be determined by the asphalt-rubber supplier dependent on the specific project requirements and conditions.

\section{Section 3.5}

Use of appropriate aggregate is essential for assuring proper performance of an asphalt-rubber SAM or SAMI. Generally, the type of aggregate required is clean, tough and durable particles of crushed rock, crushed gravel or crushed slag which is sized as a $3 / 8$ inch nominal particle size. Due to the numerous specific gradations which are used by various agencies throughout the United States, specific gradation requirements are not included in this specification. However, conformance to the following parameters is essential for selecting proper cover aggregate for asphalt-rubber SAM's or SAMI's.

1. $75 \%$ of the aggregate retained on the No. 8 sieve should have at least one fractured face.

2. The L.A. Abrasion percent wear (ASTM C 131) should not exceed 40 for SAM projects and 50 for SAMI projects.

3. The aggregate should be sufficiently dust free to yield a minus No. 200 mesh content by washing which is less than $1.0 \%$ for SAM projects and $2.0 \%$ for SAMI projects.

4. A typical gradation for $3 / 8$ nominal aggregate which has been performed successfully in yield applications of SAM's and SAMI's is as follows:

Sleve Size
$1 / 2$
$3 / 8$
$1 / 4$
$\# 8$
$\# 200$

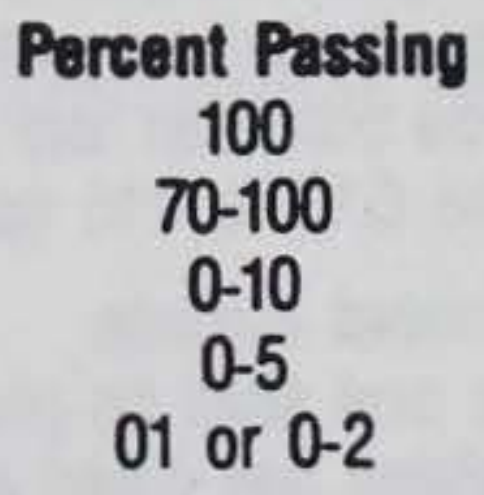

5. Slight deviations from the above gradation on the $1 / 2$ inch and $3 / 8$ inch sieves are acceptable. However, it is extremely important that the $1 / 4$ inch, №. 8 and No. 200 requirements are adhered to as excessive fineness on these screens can result in improper adhesion and embedment of the coarser sized particles which can cause early aggregate loss and flushing of the asphalt-rubber binder.

6. The use of larger sized aggregate also provides excellent results with asphalt-rubber SAM's and SAMI's, however a coarser surface texture is obtained. A typical $1 / 2$ inch nominal gradation is as follows:

\section{Sleve Size}

$5 / 8$

$1 / 2$

$3 / 8$

$1 / 4$

\#8

\#200
Percent Passing

100

95-100

$0-20$

$0-5$

$0-2$

$0-1$ or $0-2$ 
7. The use of smaller sized aggregate (1/4 inch nominal size) is not generally recommended for use with most asphalt-rubber treatments, as use of this sized aggregate can produce flushing surfaces with normal asphaltrubber application rates of .55 to .60 gallons per square yard. However, with application rates less than .5 gallons per square yard, $1 / 4$ inch aggregate may be used. A typical $1 / 4$ inch nominal gradation is as follows:

Sieve Size
$3 / 8$
$1 / 4$
$\# 8$
$\# 200$

Percent Passing
100
$70-100$
$0-5$
$0-1$

8. When asphalt-rubber is to be utilized on an airport facility, and is to be left as a SAM, consideration should be given to the texture of the aggregate. This should be done in order to reduce any possibility of damaging aircraft tires due to coarse surface texture or loss of cover aggregate causing possible propeller or jet engine damage.

9. If the aggregate common to the area has been identified to be excessively dirty, exhibits a high stripping tendency or has a high moisture content consideration should be given to the option of precoating the aggregate to help insure a quality end result project. This may be accomplished by means of hot or cold applied precoating methods. Various precoating materials and methods have been fully investigated by International Surfacing. Inc. For a copy of possible precoating options consult your International Surfacing, Inc. representative.

If precoating is included, then Section 3.1 would have to contain requirements for the asphalt materials and Section 3.5 the requirements for precoating the aggregate. With heating of the aggregate only for hot spreading, this requirement would be required in Section 3.5 .

10. Flush Coat

If non-precoated aggregate is used then a flush coat conforming to the following will be required.

Flush coats on chip seals shall consist of the application of emulsified asphalt.

Time of Application and Weather Conditions

For seal coats on new chip seals shall be applied within 48 hours. This time restriction may be extended by the engineer.

Emulsified asphalt shall not be applied when the surface is wet or when there is a threat of rain. The ambient temperature shall be at least $50^{\circ} \mathrm{F}$ and rising.

\section{Materials}

Emulsified asphalt unless otherwise specified shall be in proportions of $50 \%$ water and $50 \%$ emulsified asphalt.

\section{Preparation of Surfaces}

Immediately before applying the emulsion, the area to be surfaced shall be cleaned of all loose aggregate and/or foreign material. This will be accomplished by means of power brooms or pickup brooms supplemented by hand brooms if necessary. The fog seal shall not be applied until an inspection of the surfaces has been made by the engineer and he has determined that the surfaces are suitable.

\section{Application of Asphalt Emulsion}

The diluted material shall be well mixed before application. It shall be applied by a distributor truck, in sound mechanical condition and calibrated to insure accuracy of application. The application rate of the emulsion shall be 0.10 to 0.15 gallon per square yard. The exact rate shall be directed by the engineer.

\section{Protection of Treated Surface}

The treated chip seal shall be protected by barricades, cones or other types of traffic control devices until the asphalt emulsion has cured and will not be picked up by traffic.

\section{Payment}

Payment for the asphalt emulsion in-place shall be by the ton, diluted, by the square yard or square foot.

\section{Section 5.3}

Recommended asphalt-rubber application rates will vary, depending on the aggregate gradation which is utilized along with consideration of the degree of distress of the pavement surface. As a general rule under normal conditions the application rate will generally fall between .55 and .65 gallons per square yard.

\section{Section 5.4}

Cover material quantities generally used have been 25 to 35 pounds per square yard (for aggregate with specific gravities between 2.5 and 2.9). The actual amount selected within this range on the project should be based on the appearance of the SAM or SAMI after initial rolling. Tracking of the asphalt-rubber binder by the cover material spreader or hauling trucks is one indicator of the need for an increase in spreading rate. Adjustments from the 25 to 35 pounds per square yard rate may be necessary for aggregates with high or low specific gravities such as for slags and synthetic materials. 


\section{Asphalt Rubber Producers Group \\ 3336 NORTH 32 ND STREET, SUITE $106 \bullet$ PHOENIX, ARIZONA 85018•(602) 955-1141 \\ Guide Specification For Hot Asphalt-Rubber Membrane}

\section{Scope}

1.1 This specification shall consist of an application of a combined reacted mixture of hot paving grade asphalt and ground rubber followed immediately with a cover material.

1.2 The work involves furnishing and placing all materials on paved and unpaved surfaces in accordance with this specification.

1.3 This specification includes two known processes for the production of Asphalt-Rubber. Method $A$ uses ground vulcanized rubber and an extender oil. Method B uses ground vulcanized rubber and a Kerosene diluent. Either method is acceptable based on proper compliance with the specifications and certifications of materials.

\section{Materials}

\subsection{Asphalt Cement}

Asphalt cement shall be classified by viscosity or penetration per ASTM D-3381 and ASTM D-946. The choice of grade of asphalt cement will depend on climate, surface condition and compatibility with the ground rubber proposed.

\subsection{Extender oil (Method A)}

The extender oil shall be resinous high flash point aromatic hydrocarbon conforming to the following requirements:

Viscosity, SSU, at 100 degrees F (ASTM D-88)

Flash Point, COC, degrees F (ASTM D-92)

Molecular Analysis (ASTM D-2007): Asphaltenes percent by weight Aromatics percent by weight
2500 Min. 390 Min.

2.3 Kerosene (Method B)

The Kerosene used shall be compatible with all other materials and shall meet the following requirements:

Flash Point-Degrees F (ASTM D-92)

Initial Boiling Point-Degrees F (ASTM D-850)

Dry Point-Degrees F (ASTM D-850)

(Caution-All Kerosenes will not meet this requirement.)
80 Min.

$350 \mathrm{Min}$.

450 Max.

\subsection{Ground Rubber}

\subsubsection{Vulcanized Rubber (Method A)}

The rubber shall be vulcanized rubber scrap and contain $22 \% \pm 5 \%$ by weight of a natural rubber. It shall be free from fabric, wire, or other contaminating materials, and shall be dry and free-flowing. Not more than 4 percent by weight of a mineral powder (such as calcium carbonate) may be included to prevent sticking or caking of the rubber particles. The vulcanized ground rubber shall meet the following requirements: 
Chemical Analysis (ASTM D-297)

Natural Rubber content percent by weight $22 \pm 5 \%$

Gradation

Sieve

8

30

50

100

\section{Percent Passing}

100

$25 \cdot 50$

$5 \cdot 45$

$0-10$

\subsubsection{Ground Tire Rubber (Method B)}

The rubber shall be ground tire rubber dry and free flowing. The specific gravity of the rubber shall be $1.15 \pm 0.05$ and shall be free from fabric, wire or other contaminating materials except that up to $4 \%$ by weight of a mineral powder (such as calcium carbonate) may be included to prevent sticking and caking of the particles. The ground rubber shall meet the following gradation.

Sieve
8
10
30
50

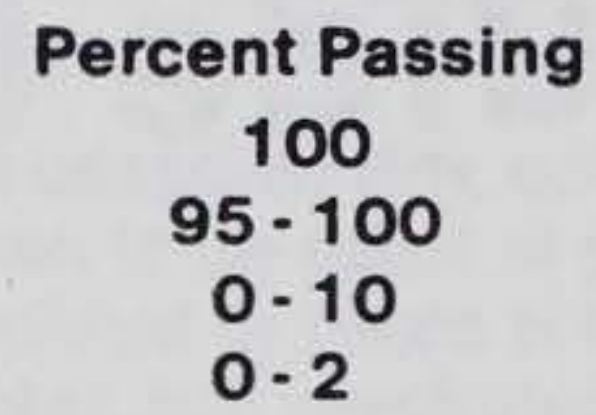

\subsection{Aggregate Cover Material (Method A \& B)}

The cover material shall consist of a dry precoated or uncoated, heated or unheated aggregate spread immediately after the application of Asphalt-Rubber seal material. The cover aggregate shall be a dry, clean material meeting the requirements of ASTM D-1139. The contract documents shall establish the precoating and/or preheating of the aggregate cover materials.

2.5.1 Proposed aggregate samples shall be submitted to the Asphalt-Rubber supplier a minimum of 21 days prior to application to test for aggregate stripping characteristics. The results shall be submitted to the engineer.

\subsubsection{Gradation}

Gradation shall be according to ASTM D-488 or ARPG recommended gradations as follows:

\begin{tabular}{cccc}
\multicolumn{4}{c}{ Percent Passing } \\
Sieve & $\begin{array}{c}3 / 8 \text { inch } \\
\text { Nominal }\end{array}$ & Nominal & $\begin{array}{c}1 / 2 \text { inch } \\
\text { Nominal }\end{array}$ \\
$3 / 4 "$ & 100 & 100 & 100 \\
$1 / 2 "$ & 100 & $97-100$ & $95-100$ \\
$3 / 8 "$ & $97-100$ & $70-100$ & $0-20$ \\
$\# 4$ & $70-100$ & $0-10$ & $0-5$ \\
$\# 8$ & $0-5$ & $0-5$ & $0-2$ \\
$\# 200$ & $0-2$ & $0-2$ & $0-2$
\end{tabular}

2.6 Tack Coat (Method A \& B)

The tack coat, when required, shall be in accordance with the specification and/or plans as directed by the Engineer.

\subsection{Fog Coat (Method A \& B)}

Fog coat shall be a SS- $1 \mathrm{~h}$ or equal emulsified asphalt diluted $50-50$ with water. The emulsified asphalt shall meet the requirements of ASTM D-977.

\subsection{Sand Blotter}

The sand shall meet the requirements of ASTM D-448 size No. 9 or as follows:

\section{Sieve \\ $3 / 8 "$}

No. 4

No. 200

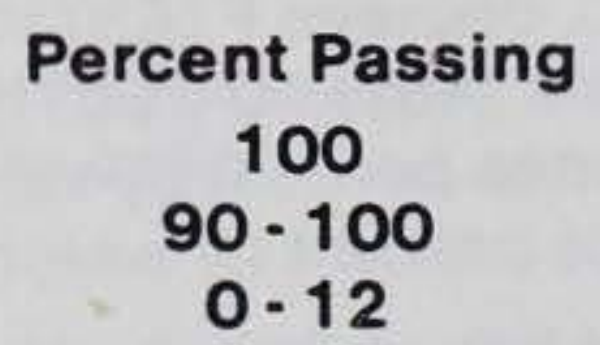

0.12

\subsection{Certification and Quality Assurance:}

Prior to application, the contractor shall submit certification of compliance to the Engineer for all materials to be used in the work

\section{Equipment}

\subsection{General}

The method and equipment for combining the rubber and asphalt shall be so designed and accessible that the Engineer can readily determine the percentage by weight for each material being incorporated into the mixture. 


\subsection{Pre-Blending}

Rubber, asphalt and extender oil for Method A shall be blended prior to introduction of the blend to the distributor. Rubber and the asphalt for Method B may be preblended prior to introduction to the distributor or blended in the distributor and diluted by Kerosene.

\subsection{Distributor:}

Distributor trucks shall be of the pressure type with insulated tanks. Spray bars and extensions shall be of the full circulating type. The spray bar shall be adjustable to permit varying height.

The nozzle spacing, center to center, shall not exceed 6 inches. The valves shall be operated so that one or all valves may be quickly opened or closed in one operation. The valve which controls the flow from the nozzles shall be of a positive acting design so as to provide a uniform, unbroken spread of Asphalt-Rubber material on the surface.

The distributor shall be equipped with devices and charts to provide for accurate, rapid determination and control of the amount of Asphalt-Rubber being applied. The distributor shall be equipped with a tachometer registering speed in feet per minute. The distributor shall also be equipped with pressure gauges and accurate thermometers for determining Asphalt-Rubber temperatures. The spraying equipment shall be designed so that uniform application of Asphalt-Rubber can be applied in controlled amounts ranging from 0.45 to 2.0 gallons per square yard plus or minus 0.05 gallons per square yard. Transverse variation rate shall not exceed ten (10) percent of the specified application rate. Distributor and booster tanks shall be maintained so as to prevent dripping of Asphalt-Rubber from any part of the equipment. The distributor must be equipped with a mechanical mixing device and truck pump.

\subsection{Rollers}

At least three pneumatic-tired self-propelled rollers or equal shall be used. Each pneumatic-tired roller shall carry a minimum of 5000 pounds on each wheel and a minimum of $100 \mathrm{psi}$ in each tire. Steel wheel rollers shall have a contact pressure of 90 pounds per-inch. Rolling speed shall be established by the engineer and shall not exceed $8 \mathrm{MPH}$. The rollers shall be approved by the engineer.

\subsection{Cover Aggregate Spreader}

A self propelled aggregate spreader shall uniformly distribute the aggregate to the hot Asphalt-Rubber composition immediately behind the distributor. The spreader shall be capable of variable widths applications within the specification application rate of plus or minus 2 pounds per square yard.

\subsection{Brooms}

face.

Brooms shall be so designed to sweep clean or redistribute aggregate without damage to the sur-

\subsection{Trucks}

Trucks of sufficient number and size to adequately supply aggregate for application rates specified. Trucks shall be scheduled, designed and equipped so that the aggregate application rate is continuous.

\section{Mixing}

\subsection{Preparation of Blend (Method A)}

4.1.1 Preparation of Asphalt-extender oil mix blend:

Blend the preheated asphalt cement ( 250 to 425 degrees $F)$ and extender oil $(0.5$ to $7 \%$ by weight) to reduce the viscosity to the application range.

\subsubsection{Preparation of Asphalt-Rubber Binder}

The asphalt extender oil blend shall be heated to a range of 350 to 425 degrees $F$. The preblended rubber shall be added to the blend at $20 \% \pm 3 \%$ of the total blend as specified by the design. Sufficient heat shall be applied to maintain the temperature between 350 and 425 degrees $F$ while circulating in the distributor. Viscosity of the Asphalt-rubber shall be in the range of 600 to 4000 centipoises at the time of application (ASTM D-2994).

\subsection{Preparation of Blend (Method B)}

The percentage of rubber shall be $22 \%(+3-4 \%)$ by weight of the total mixture. The approved mix design by the supplier will establish the needed percentage of rubber. Mixing shall continue in the temperature range of 250 degrees $F$ to 450 degrees $F$ until the reaction is complete. The viscosity of the asphalt rubber shall be in the range of 500 to 4000 centipoises as tested by ASTM D-2994 before application. The viscosity shall be set by the design for proper application and consistency.

\subsection{Adjustment of spray viscosity with diluent (Method B)}

After the full reaction has occurred the mix may be diluted with Kerosene for Method $B$. The amount of diluent used shall not exceed $7.5 \%$ by volume of the hot asphalt-rubber composition as required for adjusting viscosity for spraying or better wetting of the aggregate. Temperature of the hot composition shall not exceed the Kerosene initial boiling point at the time of adding the diluent.

\section{Construction}

Prior to placing the hot asphalt rubber seal coat, soil and other objectionable materials shall be removed from the pavement surface. The Engineer will evaluate the surface condition for the need of a tack coat. 
The application rate of the hot asphalt rubber mixture shall be 0.45 to 0.75 gallons per square yard. The engineer will establish the application rate per this specification and contract documents. Hot asphalt-rubber shall be applied at 350 degrees $F$ to 425 degrees $F$ for Method $A$ and 300 degrees $F$ to 350 degrees $F$ for Method $B$. The application of the cover aggregate shall follow as close as possible behind the distributor truck

The cover aggregate may be preheated prior to application and precoated as follows:

When specified the aggregate shall be heated to 260 degrees $F$ to 325 degrees $F$ and precoated with bituminous material. The quantity of bituminous material used shall not be less than 0.50 nor more than 0.75 percent of the combined weight of the bituminous material and the aggregate.

The final percentage of asphalt used for coating shall be directed by the Engineer. Precoating shall produce a uniform, dust free product.

Hot asphalt-rubber seal and cover aggregate shall be placed when the ambient temperature is at least 60 degrees $F$ and rising on a dry surface and no immediate threat of rain. Wind velocities shall be such that the application is directly on to the surface to be sealed only. The rate of application of the cover material shall be from 25 to 35 pounds per square yard for $1 / 4$ inch nominal as herein specified or 30 to 40 pounds per square yard for $3 / 8$ inch nominal size as directed by the engineer.

The rolling of the cover aggregate material shall follow immediately after application in order to insure embedment of the aggregate. Sufficient rollers shall be used for initial rolling to cover the width of the aggregate spread with one pass. The first pass shall be made immediately behind the aggregate spreader. If the spreading is stopped for an extended period, the spreader shall be moved so that all cover aggregate may be immediately rolled. Three complete passes with 3 rollers shall be made with all rolling completed within one hour after the application.

The contractor shall sweep all joint edges clean of overlapping cover material prior to the adjacent application of Asphalt-Rubber material. Transverse joints shall be made by placing building paper over the ends of the previous applications. The jointing application shall start on the building paper. Once the application process has progressed beyond the paper, the paper shall be removed and disposed of to the satisfaction of the Engineer. All valve, manhole, drain grate covers shall be covered prior to the application of asphalt-rubber as directed by the plans and specifications.

Traffic may be allowed on the covered surface after rolling with the following restrictions:

a. Speed not to exceed $25 \mathrm{MPH}$

b. All intersections that have traffic controls shall, as directed by the Engineer, be sanded with 2 to 5 pounds of sand per square yard. Sand shall be applied through the intersection and for 200 feet each way after rolling and before opening a lane to traffic.

c. After sweeping and prior to striping, a fog coat shall be applied, unless otherwise directed by the Engineer to the sealed surface. The fog coat shall be 0.10 to 0.15 gallons per square yard of an emulsified asphalt diluted 50-50 with water. The application of the fog coat may be delayed to facilitate curing or to avoid placement under unfavorable conditions.

\section{Measurement}

Quantities of materials for this work will be paid for at the contract price per unit of measurement for each of the following pay items actually used on the project. Payment may be made by the square yard for any or all of the items used.
(A) Aggregate Cover
(B) Hot Asphalt-Rubber (@ 325 degrees F)
(C) Emulsified Asphalt (@60 degrees F)
(D) Sand Blotter

Ton
Ton
Ton Diluted
Ton (Surface Dry)

\section{Payment}

Payment will be full compensation for furnishing and placing all materials specified and used, with no allowance for waste, and shall include labor, equipment, tools, and incidentals necessary to complete the work as prescribed and as directed by the Engineer.

Asphalt for precoating aggregate will be included in the price per ton for aggregate cover. 